\title{
WOOD UNDER FRESH WATER: EFFECT ON THE CHEMICAL PROPERTIES AND ON DECAY RESISTANCE
}

\author{
Tainise V. Lourençon ${ }^{1}$, Patrícia S. B. dos Santos ${ }^{2}$, Jalel Labidì,^, Darci A. Gatto ${ }^{3}$, Margarete R. F. \\ Gonçalves ${ }^{3}$
}

\begin{abstract}
This study aimed to evaluate the effect of waterlogging on the chemical properties and on decay resistance of two fast-growing eucalypt species. Samples of spotted gum and rose gum wood were placed underwater and taken out at different times: after 4,8 and 12 months. Chemical properties were performed via wet chemical quantification (Tappi standards), monomeric sugars by HPLC, and qualitative evaluation of extractives by Py-GC/MS and ATR-IR spectroscopy; biological performance was investigated using Trametes versicolor and Gloeophyllum trabeum rot fungi. The results showed slight changes to the chemical properties of both wood species, with an increase in lignin represented by the reduction of sugars due to waterlogging. Both species showed higher susceptibility to Gloeophyllum trabeum mainly in the sapwood, with no influence on decay resistance due the waterlogging.
\end{abstract}

Keywords: Chemical composition, decay fungi, waterlogged wood, wood extractives, wood underwater.

\section{INTRODUCTION}

Under certain conditions of exposure, wood may rapidly decompose due to organic decay or natural weathering (Hyvönen et al. 2005). The exposure to water in certain circumstances, as in constructions, in the building sector, can cause several damages to wood.

On the other hand, the conditions underwater, with moist and without air, reduces the decomposition of wood, which is evidenced by archaeological objects and ships, found after many centuries at the sea or lakes in relatively well conditions (Fojutowski et al. 2014). Besides, in some industries of forestry sector, logs are reserved underwater while wait the production process as a mean of avoiding cracks and fungi and insects deterioration (Lourençon et al. 2015).

In this context, many countries, mainly at 1950 s and 1970 s, had their forests flooded due the construction of dam projects, and since the mid-1990s this resource have been explored (Fojutowski et al. 2014). It is well know the relatively well preserved structures of these woods; however, the most part of the scientific studies are focused on culture heritage.

\footnotetext{
${ }^{1}$ Wood and Forestry Science Center (PPGEF), Federal University of Paraná, Lothário Meissner, Curitiba, Brazil.

${ }^{2}$ Chemical and Environmental Engineering Department, University of the Basque Country, Plaza Europa, Donostia-San Sebastián, Spain.

${ }^{3}$ Development Centre of Technology, Federal University of Pelotas, Félix da Cunha, Pelotas, RS. Brazil.

•Corresponding author: Jalel.labidi@ehu.eus
}

Received: 03.01.2016 Accepted: 30.08.2016 
Furthermore, studies of wood exposed to underwater conditions can be used to provide support to the search for new information about underwater archaeological objects (Björdal 1999, Jensen and Gregory 2006, Tamburini et al. 2014), flooded forests (Kooye 2011, Tenenbaum 2004), and wood underwater to preserve its structure before some industrial application.

A preliminary study showed an increase of homogeneity and specific gravity of these two eucalypt varieties after waterlogging (Lourençon et al. 2015). Nevertheless, studies related to chemical compounds and biological resistance in wood submerged to fresh water could supplemental the first investigation. To understand the role that water (as an isolated factor) plays in the submerged wood, it was chosen a non-real-world submerged wood situation, composed by a controlled environment where there was no influence of sand, mud, weathering and/or organisms.

The aim of our research was to evaluate the effect on the chemical properties and on decay resistance in spotted gum and rose gum wood caused by the submergence of samples in fresh water for twelve months.

\section{MATERIAL AND METHODS}

\section{Raw materials and experimental submergence}

Spotted gum (Corymbia citriodora Hill \& Johnson) and rose gum (Eucalyptus grandis Hill ex Maiden) wood from a fast-growing forest plantation were harvested in Southern Brazil (31 $45^{\circ} 48^{\prime \prime} \mathrm{S}$ $\left.52^{\circ} 29^{\prime} 02^{\prime \prime} \mathrm{W}\right)$. The Köppen classification of this region is Cfa. For each species, three fifty-year old trees were randomly extracted according to ASTM (1999). The first log (1 m length) of each tree was cut. Then, four small logs (each $25 \mathrm{~cm}$ ) were cut. One small log was utilized as control sample $\left(\mathrm{T}_{0}\right)$ (not submerged) and the three others were submerged in drinking water boxes (from a public network), at $\sim 20^{\circ} \mathrm{C}$, that were changed every two weeks (to avoid bacterial degradation), and taken out at different times: 4, 8 and 12 months ( $\mathrm{T}_{4}, \mathrm{~T}_{8}$ and $\mathrm{T}_{12}$ respectively). After the immersion, a central plank was cut from each small $\log$ and the sapwood was separated from heartwood by macroscopic distinction. All these samples were placed in a climatic chamber $\left(20^{\circ} \mathrm{C}\right.$ and $65 \%$ relative humidity) to stabilize the moisture content in $\sim 12 \%$. Then, samples were prepared for chemical analyses and decay resistance (Figure 1). Diagnostic checks ( $T$-test of normality and Bartlett test of homogeneity of variances) were performed in order to evaluate whether the data is suitable for analysis of variance (ANOVA) tests. When the null hypothesis was rejected, the average values were compared with a Tukey Test at the level of significance of $1 \%$.

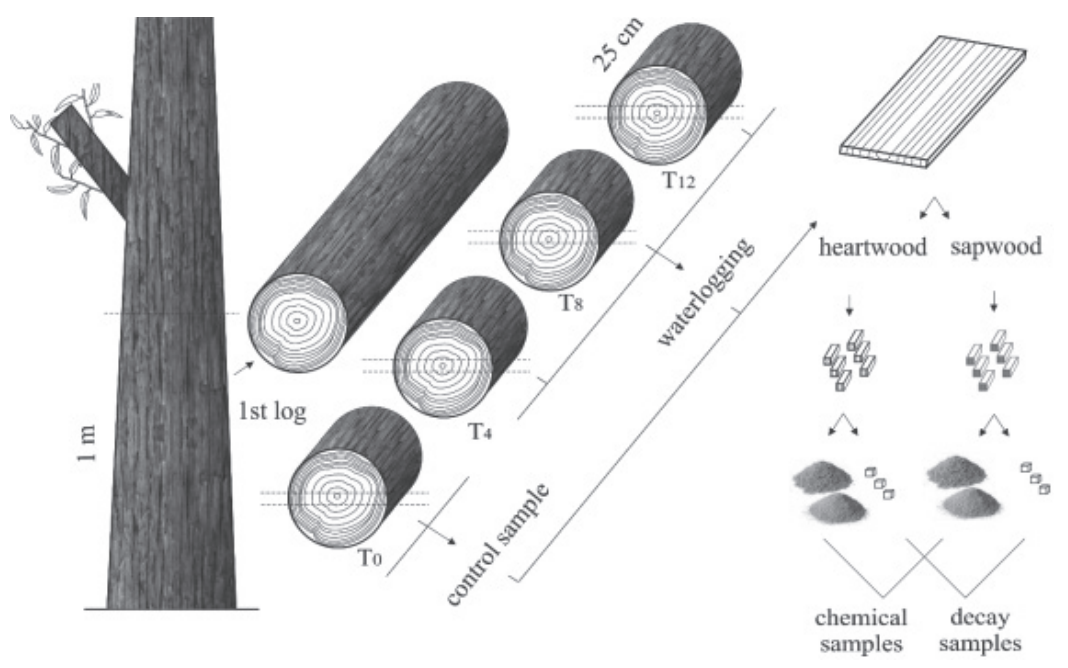

Figure 1. Scheme of sample performed. 


\section{Wet chemical quantification}

The prepared heartwood and sapwood samples were milled in a knife-mill (Willey type) and classified in 40-60 mesh (fraction 40/60), according to the procedures of TAPPI (1996). The moisture content (wet basis) of wood samples, ethanol:toluene (1:2) extractives, Klason lignin, hot water soluble substances and $\mathrm{NaOH}$ solubility ${ }_{(1 \%)}$, were determined in triplicate, according to TAPPI Standards (TAPPI, 1993, 1997a, b, 1998a, b).

\section{Monomeric sugars quantification}

High performance liquid chromatography (HPLC) was used for the quantification of the main sugars in the wood. The first filtrate from the Klason lignin test was analyzed by a Jasco LC-Net II/ ADC equipment with a photodiode array detector MD-2018Plus, refractive index detector RI-2031Plus and Rezex ROA Organic Acid $\mathrm{H}^{+}(8 \%)$ column. Dissolution of $0,005 \mathrm{~N} \mathrm{H}_{2} \mathrm{SO}_{4}$ with $100 \%$ of deionised and degassed water was used as a mobile phase. The conditions of the samples' injection were $4^{\circ} \mathrm{C}$; $0,35 \mathrm{~mL} / \mathrm{min}$ flow and volume of $20 \mu \mathrm{L}$.

\section{Classification of extractives by infrared spectroscopy (ATR-IR)}

The lipophilic extractives obtained through ethanol/toluene wood extraction (a mix of three independent replicates), at utmost times $\left(\mathrm{T}_{0}\right.$ and $\left.\mathrm{T}_{12}\right)$, were analyzed by ATR-IR spectroscopies. The study was developed in a Nicolet Nexus 570 equipment by direct transmittance in a single-reflection ATR System, at a resolution of $4 \mathrm{~cm}^{-1}$ for 32 scans ranging from $700 \mathrm{~cm}^{-1}$ to $4000 \mathrm{~cm}^{-1}$.

\section{Identification of extractives by Py-GC/MS}

The ethanol/toluene extracts, at utmost times $\left(\mathrm{T}_{0}\right.$ and $\left.\mathrm{T}_{12}\right)$, were analyzed by Pyrolysis coupled with gas chromatography/mass spectrometry (Py- GC/MS). The pyrolysis was carried out using a CDS analytical Pyrobrobe 5150. The pyrolysis temperature was set at $650^{\circ} \mathrm{C}$ for $15 \mathrm{sec}$ with a heating rate of $2^{\circ} \mathrm{C} \mathrm{msec}-1$. The products were then analyzed by a GC-MS instrument. The GC (7890A)-MS (5975C inert MSD with Triple-Axis Detector) Agilent was equipped with a capillary column HP-5MS ((5\%-Phenyl)-methylpolysiloxane, $60 \mathrm{~m} \times 0,25 \mathrm{~mm})$. Helium was used as the carrier gas. The oven program started at $50^{\circ} \mathrm{C}$ and was held for $2 \mathrm{~min}$ at this temperature. Then, it was raised to $120^{\circ} \mathrm{C}$ at $10^{\circ} \mathrm{C} / \mathrm{min}$ and held for $5 \mathrm{~min}$; raised to $280^{\circ} \mathrm{C}$ at $10^{\circ} \mathrm{C} / \mathrm{min}$, held for $8 \mathrm{~min}$ and finally raised to $300^{\circ} \mathrm{C}$ at $10^{\circ} \mathrm{C} / \mathrm{min}$ and held for $10 \mathrm{~min}$. For the characterization of extractives, identified through NIST08 Mass Spectral Library, as a selection criteria, were discarded compounds area less than $1 \%$, and after that, only compounds with $70 \%$ of minimum probability of certainty were considered, summarizing 32 main compounds.

\section{Resistance of wood to Trametes versicolor and Gloeophyllum trabeum}

Decay resistance of submerged woods was evaluated by in vitro tests, according to PN-EN113 Standard (PN-EN113 2000), adapted. Potato agar was used as substrate and Gloeophyllum trabeum (Persoon ex Fries) Murrill and Trametes versicolor (Linnaeus ex Fries) Pilat fungi were used to promote brown and white decay, respectively. Nine samples of each wood, specie and time were separately exposed to decay for 16 weeks.

Mass loss after fungal attack was calculated by the difference between the oven-dried mass of the samples before and after the test. 


\section{RESULTS AND DISCUSSION}

\section{Chemical evaluation of wood}

There was no statistical difference in the content of lipophilic extractives (ethanol/toluene) as a function of waterlogging (Table 1). These were expected results due to extractives type - only extracted by nonpolar solvents; hence, not removable by water (polar). Differently, the results reported by Fojutowski et al. (2014), showed a decrease of extractives in oak wood (without specific analysis between heartwood and sapwood) after two years underwater, probably due to longer time underwater, salt and other environment influences.

Table 1. Chemical quantification of spotted gum and rose gum wood over a period of one year submerged.

\begin{tabular}{|c|c|c|c|c|c|c|c|c|c|}
\hline \multirow[b]{2}{*}{ Content $(\%)$} & & \multicolumn{4}{|c|}{ Spotted gum } & \multicolumn{4}{|c|}{ Rose gum } \\
\hline & & $\begin{array}{l}\text { heartwood } \\
\text { Mean (SD) }\end{array}$ & F-ratio & sapwood & F-ratio & heartwood & F-ratio & sapwood & F-ratio \\
\hline \multirow{4}{*}{ Extractives } & $\mathrm{T}_{0}$ & $5,7(0,9)$ & \multirow{4}{*}{$1,3^{\text {ns }}$} & $1,9(0,2)$ & \multirow{4}{*}{$2,8^{\mathrm{ns}}$} & $2,1(0,9)$ & \multirow{4}{*}{$2,0^{\mathrm{ns}}$} & $2,3(0,9)$ & \multirow{4}{*}{$1,2^{\mathrm{ns}}$} \\
\hline & $\mathrm{T}_{4}$ & $6,8(1,8)$ & & $1,4(0,4)$ & & $2,1(0,5)$ & & $1,7(0,2)$ & \\
\hline & $\mathrm{T}_{8}$ & $7,0(1,3)$ & & $1,5(0,0)$ & & $3,1(1,0)$ & & $1,7(0,5)$ & \\
\hline & $\mathrm{T}_{12}$ & $6,9(1,2)$ & & $1,3(0,5)$ & & $2,4(0,1)$ & & $2,1(0,7)$ & \\
\hline \multirow{4}{*}{$\begin{array}{l}\text { Hot water } \\
\text { solubility }\end{array}$} & $\mathrm{T}_{0}$ & $5,4(0,5) a$ & \multirow{4}{*}{$8,0^{* *}$} & $2,9(1,7)$ & \multirow{4}{*}{$0,7^{\mathrm{ns}}$} & $4,0(1,9)$ & \multirow{4}{*}{$2,3^{\mathrm{ns}}$} & $2,9(0,8)$ & \multirow{4}{*}{$3,5^{\text {ns }}$} \\
\hline & $\mathrm{T}_{4}$ & $5,0(0,4) a$ & & $3,5(1,6)$ & & $2,0(1,0)$ & & $4,1(1,3)$ & \\
\hline & $\mathrm{T}_{8}$ & $6,0(1,9) a$ & & $2,5(1,0)$ & & $3,9(1,7)$ & & $2,4(1,6)$ & \\
\hline & $\mathrm{T}_{12}$ & $8,0(0,1) b$ & & $2,5(0,4)$ & & $3,6(0,8)$ & & $4,4(0,8)$ & \\
\hline \multirow{4}{*}{$\begin{array}{c}\mathrm{NaOH} \\
\text { solubility }_{(1 \%)}\end{array}$} & $\mathrm{T}_{0}$ & $15,9(2,0)$ & \multirow{4}{*}{$0,5^{\text {ns }}$} & $9,6(2,0)$ & \multirow{4}{*}{$0,7^{\mathrm{ns}}$} & $20,8(2,2)$ & \multirow{4}{*}{$0,5^{\text {ns }}$} & $10,6(0,5)$ & \multirow{4}{*}{$0,3^{\text {ns }}$} \\
\hline & $\mathrm{T}_{4}$ & $14,7(2,8)$ & & $11,9(2,4)$ & & $20,6(2,7)$ & & $10,4(0,6)$ & \\
\hline & $\mathrm{T}_{8}$ & $15,3(4,1)$ & & $11,4(1,7)$ & & $17,7(1,4)$ & & $9,8(1,6)$ & \\
\hline & $\mathrm{T}_{12}$ & $18,5(3,1)$ & & $10,1(2,1)$ & & $21,6(4,2)$ & & $9,8(1,1)$ & \\
\hline \multirow{4}{*}{$\begin{array}{c}\text { Insoluble } \\
\text { lignin }\end{array}$} & $\mathrm{T}_{0}$ & $26,7(3,3) a b$ & \multirow{4}{*}{$9,3^{* *}$} & $22,1(1,2) a$ & \multirow{4}{*}{$28,0^{* *}$} & $30,8(0,4) a$ & \multirow{4}{*}{$11,3^{* *}$} & $25,9 a$ & \multirow{4}{*}{$19,9^{* *}$} \\
\hline & $\mathrm{T}_{4}$ & $22,2(1,1) a$ & & $20,0(2,9) a$ & & $27,3(5,4) a$ & & $25,3 a$ & \\
\hline & $\mathrm{T}_{8}$ & $35,4(3,7) c$ & & $34,2(3,1) b$ & & $41,3(4,3) b$ & & $35,2 b$ & \\
\hline & $\mathrm{T}_{12}$ & $32,5(4,7) b c$ & & $30,8(3,1) b$ & & $40,2(1,8) b$ & & $34,8 \mathrm{~b}$ & \\
\hline
\end{tabular}

**Significant at $99 \%$ of confidence level. ns: not significant

The only difference in hot water-soluble compounds results was an increase at $\mathrm{T}_{12}$ in the heartwood for spotted gum. This isolated result could be associate to the available situation of the heartwood samples in the hot water analysis (able to be extracted by water), different from the waterlogging. The $\mathrm{NaOH}_{(1 \%)}$ solubility results could not be used to evaluate differences by the waterlogging, as well.

Higher differences are found for the lignin content (Table 1) which, for both species and woods, presented an increase from $\mathrm{T}_{8}$. Increased lignin due to wood waterlogging has been observed (Fojutowski et al. 2014). The highest lignin percentage presented in the last two times $\left(\mathrm{T}_{8}\right.$ and $\left.\mathrm{T}_{12}\right)$ is related to the reduced values of other wood components that can be extracted or degraded with water, such as salts, simple carbohydrates, polysaccharides and some phenolic substances (Silvério 2008). In addition, Krogell et al. (2013) and Song et al. (2013) have previously shown that hemicellulose can be obtained using water as solvent.

Therefore, if the carbohydrate content (Figure 2) has lower values as a function of time, the lignin proportion - difficult to extract due to an amorphous and complex structure (Chakar and Ragauskas 2004) -presented higher values, compensating the reduction in proportion, since the balance should add up to $100 \%$. An analogy can be made with wood heat treatment, wherein the proportional increase of lignin occurs due to thermal decomposition of the hemicelluloses (Esteves et al. 2011, Mohareb et al. 2012). 

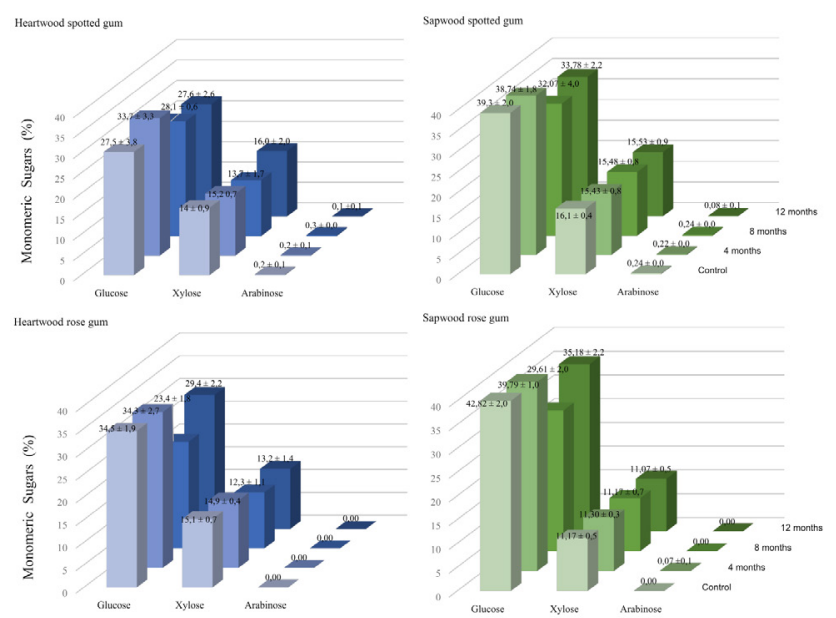

Figure 2. Monomeric sugars in heartwood and sapwood of spotted gum and rose gum.

\section{Chemical evaluation of extractives}

The ATR-IR spectra of extractives from waterlogged wood and control samples for both spotted gum and rose gum are shown in Figure 3. The band at $1030 \mathrm{~cm}^{-1}$ related to C-O stretching (ether bond), present in carbohydrates, aromatic compounds (Barbosa et al. 2005) and alcohols (Silverstein et al. 2005), decreased in the waterlogged $\left(\mathrm{T}_{12}\right)$ sapwood samples for spotted gum due to a possible removal of some carbohydrates with waterlogging. For the rose gum extractives, no specific behavior was observed.
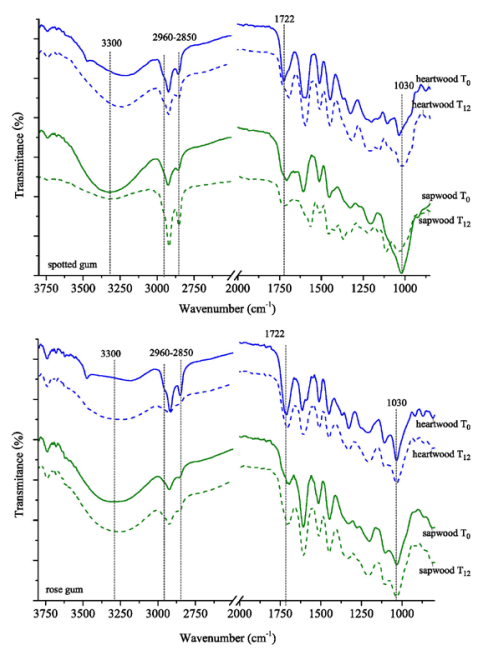

Figure 3. ATR-IR spectra of extractives of spotted gum and rose gum wood.

The band at $1722 \mathrm{~cm}^{-1}$ related to $\mathrm{C}=\mathrm{O}$ stretching present in carboxylic acid, aldehydes, esters and ketone (Barbosa et al. 2005, Silverstein et al. 2005) had a higher intensity in the heartwood of spotted gum and sapwood of rose gum; such a difference is associated with the distinct chemical composition of each species.

The C-H (methyl and methylenes) bond vibration at 2960-2850 is common to several classes of aliphatic compounds such as fatty acids and esters, long-chain alcohols and steroids (Silvério 2008, 
Silverstein et al. 2005, Sócrates 1979). The highest intensity of this region was observed in the sapwood at $\mathrm{T}_{12}$ for spotted gum, related to extractive compounds with these substances.

The band at 3300 related to $\mathrm{OH}$ stretching indicates the presence of carboxylic acids and alcohols (Barbosa et al. 2005, Silvério 2008). In the sapwood of spotted gum, a decrease of this band's intensity at $\mathrm{T}_{12}$ can be observed, which indicates a decrease in hydroxyl groups (Ajuong and Breese 1998), possibly removed by water in the waterlogging. For the rose gum, the higher intensity in the sapwood for both times $\left(\mathrm{T}_{0}\right.$ and $\left.\mathrm{T}_{12}\right)$ is clear.

In addition, thirty-two major compounds with highest concentrations in the extractives of sapwood and heartwood for both species were identified by Py-GC/MS analysis (Figure 4). The active principles with their retention time (RT) and the percentage of the total area in the extractives for both species are presented in Table 2.

For spotted gum, an increase in the phenolics and polyphenolic compounds (peaks 5, 11, 16, 17 and 19), from $\mathrm{T}_{0}$ to $\mathrm{T}_{12}$, and a decrease for limonene (peak 6) were observed in the heartwood, while the phenolic compounds (peaks 16 and 19) decreased and the limonene increased (peak 6) in the sapwood.

The phenolic and terpene compounds are the main cause for the natural decay resistance of the wood (Costa et al. 1997, Mossi et al. 2010). Thus, on one hand, the resistance of sapwood decreases with a reduction in phenolics, while on the other, it increases with the terpene increase.

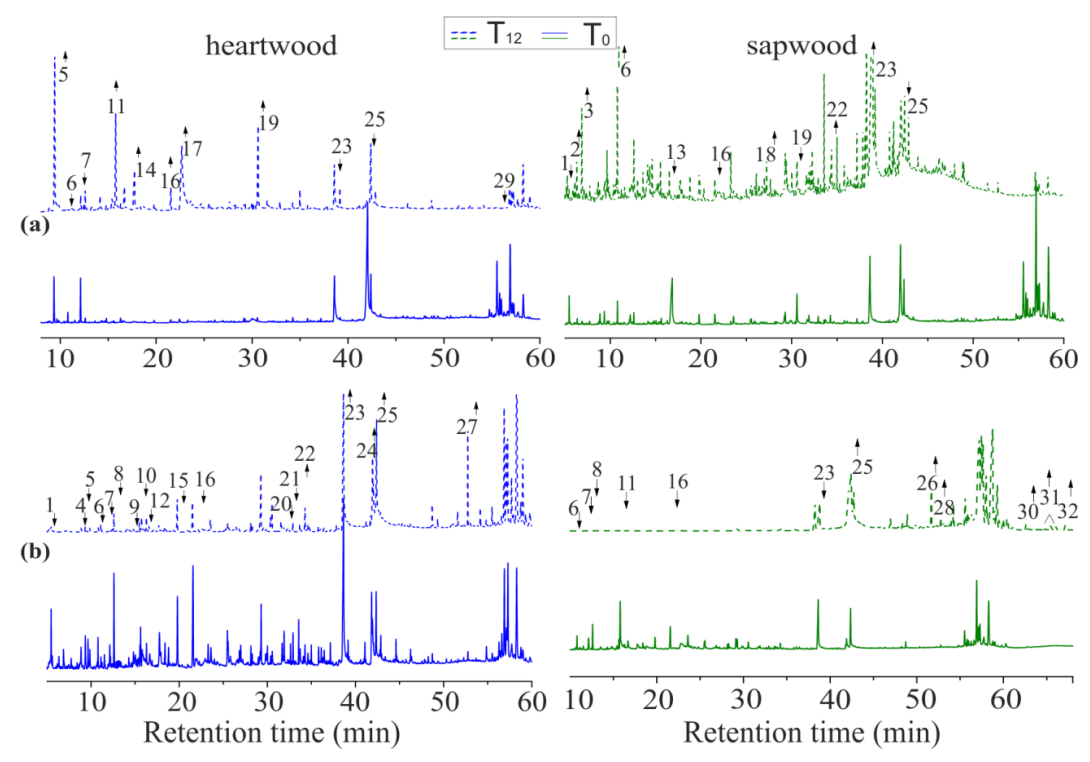

Figure 4. Chromatogram of lipophilic extractives from heartwood and sapwood of Corymbia citriodora (a) and Eucalyptus grandis (b) for control samples $\left(\mathrm{T}_{0}\right)$ and waterlogged samples $\left(\mathrm{T}_{12}\right)$.

The fatty acids (peaks 23 and 25) of heartwood showed a reduction from $\mathrm{T}_{0}$ to $\mathrm{T}_{12}$. Conversely, in the sapwood (peaks 22 and 23) fatty acids were higher in $\mathrm{T}_{12}$. This behavior was confirmed by band $2960-2850 \mathrm{~cm}^{-1}$ in the ATR-IR analysis, where the highest intensity was observed for the sapwood at $\mathrm{T}_{12}$. 
Table 2. Composition of lipophilic extractives from heartwood and sapwood for both spotted gum and rose gum.

\begin{tabular}{|c|c|c|c|c|c|c|c|c|c|c|}
\hline & & & \multicolumn{4}{|c|}{ Spotted gum } & \multicolumn{4}{|c|}{ Rose gum } \\
\hline \multirow{3}{*}{ Peak } & \multirow{3}{*}{ RT } & \multirow{3}{*}{ Compound } & \multicolumn{2}{|c|}{ Heartwood } & \multicolumn{2}{|c|}{ Sapwood } & \multicolumn{2}{|c|}{ Heartwood } & \multicolumn{2}{|c|}{ Sapwood } \\
\hline & & & \multicolumn{4}{|c|}{$\%$ Area } & \multicolumn{4}{|c|}{$\%$ Area } \\
\hline & & & $\mathrm{T}_{0}$ & $\mathrm{~T}_{12}$ & $\mathrm{~T}_{0}$ & $\mathrm{~T}_{12}$ & $\mathrm{~T}_{0}$ & $\mathrm{~T}_{12}$ & $\mathrm{~T}_{0}$ & $\mathrm{~T}_{12}$ \\
\hline 1 & 5,47 & Furfural & - & - & 1,14 & 0 & 1,13 & 0,18 & - & - \\
\hline 2 & 6,32 & p-xylene & - & - & 0,28 & 0,35 & - & - & - & - \\
\hline 3 & 6,86 & Styrene & - & - & 0,21 & 1,02 & - & - & - & - \\
\hline 4 & 8,86 & 2-Furancarboxaldehyde, 5-methyl- & - & - & - & - & 0,61 & 0,18 & - & - \\
\hline 5 & 9,5 & Phenol & 2,56 & 8,75 & - & - & 0,82 & 0,16 & - & - \\
\hline 6 & 10,8 & Limonene & 0,49 & 0,04 & 0,79 & 1,01 & - & - & - & - \\
\hline 6 & 10,8 & D-limonene & - & - & - & - & 0,5 & 0,13 & 0,60 & 0 \\
\hline 7 & 12,12 & Phenol, 4-methyl & 2,41 & 0,66 & - & - & 0,51 & 0,10 & 0,87 & 0,01 \\
\hline 8 & 12,6 & Phenol, 2-methoxy- & - & - & - & - & 1,68 & 0,39 & 1,15 & 0,01 \\
\hline 9 & 14,8 & Phenol, 2-ethyl- & - & - & - & - & 0,5 & 0,16 & - & - \\
\hline 10 & 15,62 & Phenol, 2-methoxy-4-methyl- & - & - & - & - & 0,68 & 0,09 & - & - \\
\hline 11 & 16 & Benzenediol & 0 & 5,76 & - & - & - & - & - & - \\
\hline 11 & & 1,2-Benzenediol & - & - & - & - & - & - & 5,75 & 0,02 \\
\hline 12 & 16,28 & Benzofuran, 2,3-dihydro- & - & - & - & - & 0,47 & 0,35 & - & - \\
\hline 13 & 16,7 & 2 -furancarboxaldehyde, 5 - (hydroxymethyl) & - & - & 6,88 & 0,16 & - & - & - & - \\
\hline 14 & 17,75 & 2- propenoic acid, 2-methyl-, 2-methylpropyl ester methylpropyl ester & 0 & 3,43 & - & - & - & - & - & - \\
\hline 15 & 19,8 & 2-Methoxy-4-vinylphenol & - & - & - & - & 1,90 & 1,03 & - & - \\
\hline 16 & 21,52 & Phenol, 2,6-dimethoxy & 0,32 & 1,14 & 0,55 & 0,29 & 3,11 & 1,03 & 1,92 & 0,02 \\
\hline 17 & $22-23$ & 1,2,4-Benzenetriol & 0,18 & 9,65 & - & - & - & - & - & - \\
\hline 18 & 27,24 & Pentadecane & - & - & 0,12 & 0,35 & - & - & - & - \\
\hline 19 & 30,56 & Phenol, 3,4,5-trimethoxy- & 0,39 & 5,13 & 1,72 & 0,54 & - & - & - & - \\
\hline 20 & 31,9 & Benzaldehyde, 4-hydroxy-3,5-dimethoxy- & - & - & - & - & 0,89 & 0,19 & - & - \\
\hline 21 & 32,9 & Phenol, 2,6-dimethoxy-4-(2-propenyl)- & - & - & - & - & 0,58 & 0,21 & - & - \\
\hline 22 & 34,35 & Tetradecanoic acid & - & - & 0,37 & 0,91 & 0,5 & 0,75 & - & - \\
\hline 23 & 38,58 & n-hexadecanoic acid & 6,36 & 3,28 & 6,41 & 9,53 & 7,8 & 9,73 & 5,88 & 4,07 \\
\hline 24 & 41,93 & Oleic acid & & & & & 2,25 & 4,44 & & \\
\hline 25 & 42,38 & Octadecanoic acid & 20,8 & 4,50 & 8,51 & 3,50 & 2,33 & 7,1 & 4,81 & 10,05 \\
\hline 26 & 51,7 & Succinic acid, decyl 5-methoxy-3-methylphenyl ester & - & - & - & - & - & - & 0,07 & 1,89 \\
\hline 27 & 52,75 & Squalene & - & - & - & - & 0,19 & 1,93 & & \\
\hline 28 & 52,76 & 2,6,10,14,18,22-Tetracosahexaene, 2,6,10,15,19,23-hexamethyl-, (all-E)- & - & - & - & - & - & - & 0 & 0,55 \\
\hline
\end{tabular}

RT - Retention time (min); $\mathrm{T}_{0}$-control samples $\mathrm{T}_{12}$ - time 12 months.

The phenolic compounds (heartwood: peaks 5, 7, 8, 9, 10 and 16; sapwood: peaks 7, 8, 11 and 16) and limonene (heartwood and sapwood: peak 6) decreased at $T_{12}$. Rose gum wood extractives presented higher phenolic compounds in the heartwood than spotted gum.

However, the fatty acids in the heartwood (peaks 22, 23, 24 and 25) and sapwood (peak 25) increased at $\mathrm{T}_{12}$, which corroborates with the ATR-IR results; a higher intensity in the region 2960$2850 \mathrm{~cm}^{-1}$ that includes these compound classes. In this work, the fatty acids represent the higher areas in the rose gum extractives composition (both in the sapwood and in heartwood) and are the main constituents of this species (Barbosa et al. 2005, Kilulya et al. 2012, Silvestre et al. 2001).

The results showed that there was a partial migration of extractives compounds in both directions of the wood (from heartwood to sapwood and from sapwood to heartwood) and also to water, producing a phenomena of diffusion and counter-diffusion. However, there was no increase or decrease observation in the extractives content (Table 1) appearing due to waterlogging, at any time, only changes in their composition.

\section{Wood decay resistance}

The results of the wood mass loss (Table 3 ) showed greater susceptibility of both wood species to Gloeophyllum trabeum (Gt) fungus. This brown-rot fungus degrades preferentially polysaccharides of wood and partially oxidizes the lignin (Aguiar and Ferraz 2012, Hammel et al. 2002). Also, both wood species and fungi showed a higher mass loss in the sapwood (Motta et al. 2013) and consequently better decay resistance in the heartwood (Costa et al. 2003, Wiedenhoeft 2010) mainly due to the higher content of phenolic extractives in this wood. 
Table 3. Mass loss of spotted gum and rose gum wood exposed to Trametes versicolor and Gloepyllum trabeum attack.

\begin{tabular}{|c|c|c|c|c|c|}
\hline \multirow{4}{*}{ Specie } & \multirow{4}{*}{$\begin{array}{l}\text { Exposure } \\
\text { time }\end{array}$} & \multicolumn{2}{|c|}{ Trametes versicolor } & \multicolumn{2}{|c|}{ Gloeopyllum trabeum } \\
\hline & & heartwood & sapwood & & sapwood \\
\hline & & \multicolumn{4}{|c|}{ Mass loss (\%) } \\
\hline & & Mean \pm S.D. & Mean \pm S.D. & Mean \pm S.D. & Mean \pm S.D. \\
\hline \multirow{4}{*}{$\begin{array}{l}\text { spotted } \\
\text { gum }\end{array}$} & $\mathrm{T}_{0}$ & $2,04 \pm 0,57$ & $3,95 \pm 1,10$ & $5,67 \pm 1,51$ & $14,11 \pm 3,83$ \\
\hline & $\mathrm{T}_{4}$ & $2,15 \pm 0,71$ & $3,1 \pm 1,08$ & $5,78 \pm 2,68$ & $16,26 \pm 9,32$ \\
\hline & $\mathrm{T}_{8}$ & $1,90 \pm 0,52$ & $4,41 \pm 2,83$ & $3,02 \pm 0,83$ & $16,4 \pm 4,03$ \\
\hline & $\mathrm{T}_{12}$ & $1,40 \pm 0,28$ & $3,88 \pm 1,97$ & $3,53 \pm 1,08$ & $13,84 \pm 5,32$ \\
\hline \multirow[t]{2}{*}{ F-ratio } & & $1,90^{n s}$ & $0,43^{\text {vis }}$ & $3,30^{0,9}$ & $0,48^{\mathrm{ns}}$ \\
\hline & $\mathrm{T}_{0}$ & $0,57 \pm 0,24$ & $1,33 \pm 0,50$ & $1,38 \pm 0,52$ & $23,06 \pm 4,17$ \\
\hline rose & $\mathrm{T}_{4}$ & $0,62 \pm 0,31$ & $0,95 \pm 0,55$ & $2,34 \pm 1,35$ & $23,32 \pm 4,76$ \\
\hline \multirow[t]{2}{*}{ gum } & $\mathrm{T}_{8}$ & $0,71 \pm 0,12$ & $1,19 \pm 0,77$ & $1,99 \pm 1,57$ & $25,98 \pm 4,32$ \\
\hline & $\mathrm{T}_{12}$ & $0,91 \pm 0,18$ & $1,18 \pm 0,97$ & $0,99 \pm 0,85$ & $18,03 \pm 3,07$ \\
\hline F-ratio & & $2,62^{n s}$ & $0,32^{n+3}$ & $1,54^{108}$ & $2,31^{\text {ns }}$ \\
\hline
\end{tabular}

S.D.- standard deviation. ${ }^{\mathrm{n}}$ not significant

As can be seen in Table 3, the wood decay resistance did not change as a function of waterlogging in fresh water. Otherwise, wood submerged in seawater showed a decrease after 6 months (Fojutowski et al. 2011), 1 year (Pomian et al. 2010) and 2 years (Fojutowski et al. 2014).

Differences between the studies are mainly due to means of submersion. Wood submerged in seawater has the possibility of suffering an initial weakening by marine organisms, which would consequently cause further degradation in the fungi tests, since the material structure was previously decayed, thus facilitating an enzyme attack during the rot samples.

\section{CONCLUSIONS}

Waterlogging of spotted gum and rose gum wood may cause an increase in lignin content due to the reduction of sugars, naturally extracted by water. Concerning to biological results, this work showed neither improvement nor decrease on decay resistance of submerged wood.

\section{ACKNOWLEDGEMENTS}

The authors would like to thank CNPq (National Counsel of Technological and Scientific Development), CAPES (Coordination for the Improvement of Higher Education Personnel) and the Department of Education, Universities and Investigation of the Basque Government (project IT67213 ), for financially supporting this work.

\section{REFERENCES}

Aguiar,A.; Ferraz,A. 2012. Effect of aqueous extracts from Ceriporiopsis subvermispora-biotreated wood on the decolorization of Azure B by Fenton-like reactions. International Biodeterioration \& Biodegradation 74:61-66.

Ajuong, E.M.A.; Breese, M.C. 1998. Fourier Transform Infrared characterization of Pai wood (Afzelia africana Smith) extractives. Holz als Roh- und Werkstoff 56:139-142.

ASTM, 1999. Standard methods of testing small clear specimens of timber, ASTM: D5536-99. Annual Book of ASTM. Philadelphia. 
Barbosa, L.C.D.; Maltha, C.R.A. Cruz, M.P. 2005. Composição química de extrativos lipofílicos e polares de madeira de Eucalyptus grandis. Revista Ciência \& Engenharia 2:13-20.

Björdal, C. G.; Nilsson, T.; Daniel, G. 1999. Microbial decay of waterlogged archaeological wood found in Sweden Applicable to archaeology and conservation. International Biodeterioration \& Biodegradation 43:63-73.

Chakar, F.S.; Ragauskas, A.J. 2004. Review of current and future softwood kraft lignin process chemistry. Industrial Crops and Products 20:131-141.

Costa, C.G.; Callado, C.H.; Coradin, V.T.R.; Carmello-Guerreiro, S.M. 2003. Xilema, in: Appezzato-Da-Gloria, B.C.-G., S. M. (Ed.), Anatomia Vegetal. UFV, Viçosa, pp. 129-154.

Costa, M.M.; Gomide, J.L.; Colodette, J.L.; Foelkel, C.E.B. 1997. Produção de polpa solúvel totalmente isenta de cloro a partir de Eucalyptus spp, CONGRESSO ANUAL DE CELULOSE E PAPEL, São Paulo, pp. 115-125.

Esteves, B.; Videira, R.; Pereira, H. 2011. Chemistry and ecotoxicity of heat-treated pine wood extractives. Wood Science and Technology 45:661-676.

Fojutowski, A.; Wróblewska, H.; Komorowicz, M.; Kropacz, A.; Noskowiak, A. Pomian, I. 2014. Changes in the properties of English oak wood (Quercus robur L.) as a result of remaining submerged in Baltic Sea waters for two years. International Biodeterioration \& Biodegradation 86, Part B, 122-128.

Fojutowski, A.; Wróblewska, H.; Kropacz, A.; Komorowicz, M.; Noskowiak, A. 2011. Chosen properties of oak wood submerged for 6 months in the Baltic Sea. Folia Forestalia Polonica 42:17-30.

Hammel, K.E.; Kapich, A.N.; Jensen, K.A.; Ryan, Z.C. 2002. Reactive oxygen species as agents of wood decay by fungi. Enzyme and Microbial Technology 30:445-453.

Hyvönen, A.; Piltonen, P.; Niinimäki, J. 2005. Biodegradable substances in wood protection, in: JALKANEN, A.N., P. (Ed.), Sustainable use of renewable natural resources - from principles to practices. University of Helsinki Department of Forest Ecology publications.

Jensen, P.; Gregory, D.J. 2006. Selected physical parameters to characterize the state of preservation of waterlogged archaeological wood: a practical guide for their determination. Journal of Archaeological Science 33:551-559.

Kilulya, K.F.; Msagati, T.A.M.; Mamba, B.B.; Ngila, J.C.; Bush, T. 2012. Controlling the release of wood extractives into water bodies by selecting suitable eucalyptus species. Physics and Chemistry of the Earth, Parts A/B/C 50-5:217-223.

Kooye, V.D. 2011. Suriname percebe vantagens nas madeiras inundadas.[on line] $<$ http://www. oecoamazonia.com.>[consulted 12, july 72012 ]

Krogell, J.; Korotkova, E.; Eränen, K.; Pranovich, A.; Salmi, T.; Murzin, D.; Willför, S. 2013. Intensification of hemicellulose hot-water extraction from spruce wood in a batch extractor - Effects of wood particle size. Bioresource Technology 143: 212-220.

Lourençon, T.V.; Gonçalves, M, R.F.; Gatto, D.A.; Labidi, J.; Serrano, L.; Mattos, B.D. 2015. Efeito do encharcamento prolongado no comportamento físico-mecânico das madeiras de Corymbia citriodora e Eucalyptus grandis. Scientia Forestalis 43:9-18.

Mohareb, A.; Sirmah, P.; Pétrissans, M.; Gérardin, P. 2012. Effect of heat treatment intensity on wood chemical composition and decay durability of Pinus patula. European Journal of Wood and Wood Products 70:519-524. 
Mossi, A.J.; Mazutti, M.A.; Cansian, R.L.; Oliveira, D.; Oliveira, J.V.; Dallago, R.; LeontievOrlov, O.; Treichel, H. 2010. Variabilidade química de compostos orgânicos voláteis e semivoláteis de populações nativas de maytenus ilicifolia. Química Nova 33: 1067-1070.

Motta, J.P.; Oliveira, J.T.S.; Paes, J.B.; Alves, R.C.; Vidaurre, D.G.B. 2013. Resistência natural da madeira de Tectona grandis em ensaio de laboratório. Ciência Rural 43:1393-1398.

PN-EN113. 2000. Wood preservatives-Test method for determining the protective effectiveness against wood destroying basidiomycetes-Determination of the toxic values.

Pomian, I.; Fojutowski, A.; Wróblewska, H.; Komorowicz, M.; Kropacz, A.; Noskowiak, A. 2010. Research on wood submerged in the sea. Drewno Pr Nauk Donies Komunik. 53:101-111.

Silvério, F.O. 2008. Caracterização de extrativos de madeira de Eucalyptus e epósitos de pitch envolvidos na fabricação de polpa e celulose, Instituto de Ciências Exatas. Universidade Federal de Minas Gerais, Belo Horizonte, p. 157f.

Silverstein, R.M.; Webster, F.X.; Kiemle, D.J. 2005. Spectrometric identification of organic compounds. John Wiley \& Sons.

Silvestre, A.J.D.; Freire, C.S.R.; Pascoal-Neto, C. 2001. Eucalyptus globulus wood extractives: Composition and fate during pulping and bleaching. Proceedings of 7 th Brazilian Symposium on the Chemistry of Lignins and other Wood Components - Oral Presentations, Belo Horizonte, Brazil, p. 69-76.

Sócrates, G. 1979. Infrared characteristic group frequencies. John Wiley e Sons, Canada.

Song, T.; Pranovich, A.; Holmbom, B. 2013. Separation of polymeric galactoglucomannans from hot-water extract of spruce wood. Bioresource Technology 130:198-203.

Tamburini, D.; Lucejko, J.J.: Modugno, F.; Colombini, M. P. 2014. Characterisation of archaeological waterlogged wood from Herculaneum by pyrolysis and mass spectrometry. International Biodeterioration \& Biodegradation 86:142-149.

TAPPI. 1993. T207 om-93, Water solubility of wood and pulp Atlanta.

TAPPI. 1996. T257 cm-85, Sampling and preparing wood for analysis, Atlanta.

TAPPI. 1997a. T204 cm-97, Solvent Extractives of Wood and Pulp, Atlanta.

TAPPI. 1997b. T264 cm-97, Preparation of wood for chemical analysis, Atlanta.

TAPPI. 1998a. T212 om-98, One percent sodium hydroxide solubility of wood and pulp, Atlanta.

TAPPI. 1998b. T222 om-98, Acid-insoluble Lignin in Wood and Pulp, Atlanta.

Tenenbaum, D. 2004. Underwater Logging: Submarine Rediscovers Lost Wood. Environmental Health Perspectives 112: A892-A895.

Wiedenhoeft, A. 2010. Structure and Function of Wood, in: Bergman, R.C., Zhiyong; Carll, Charlie G.; Clausen, Carol A.; Dietenberger, Mark A.; Falk, Robert H.; Frihart, Charles R.; Glass, Samuel V.; Hunt, Christopher G.; Ibach, Rebecca E.; Kretschmann, David E.; Rammer, Douglas R.; Ross, Robert J. (Ed.), Wood Handbook: Wood as an Engineering Material. Dept. of Agriculture, Forest Service, Forest Products Laboratory, Madison: U.S. , pp. 3.1-3.18. 